https://nv.nltu.edu.ua

https://doi.org/10.36930/40290807

\title{
ТАКСОНОМІЧНА СТРУКТУРА І СТАН ВУЛИЧНИХ НАСАДЖЕНЬ МІСТА ХЕРСОН
}

Під найбільший антропогенний прес у містах потрапляють деревні насадження вздовж вулиць та автомагістралей. Згідно зі статистичними даними, найбільшим забруднювачем повітря Херсона $є$ автомобільний транспорт. Тому дослідження дендрофлори лінійних насаджень автодоріг з високим антропогенним навантаженням, аналіз їх видового складу, санітарного стану, придатність у використанні об'єктів спеціального призначення належать до актуальних проблем сучасного міста. За результатами наших досліджень, у вуличних насадженнях Херсона виявлено 59 видів деревних рослин, 3 культивари та 3 форми. У таксономічній структурі представленої дендрофлори за кількістю видів переважає відділ Magnoliophyta (55 види, 93,2 \%). Відділ Pinophyta представлений лише чотирма видами $(6,8 \%)$. Провідними родинами дендрофлори проспектів $\epsilon$ Rosaceae Juss. (7 видів), що становить 11,9\% від загальної кількості видів та Salicaceae Lindl. (6 видів, 10,2 \%), Oleaceae Lindl. (5 видів, 8,5\%), Aceraceae Juss. (4 види, 6,8 \%), Fabaceae Lindl. (4 види, 6,8 \%) та Cupressaceae Bartl. (3 види, 5,1 \%). Зазначені родини охоплюють 49,3 \% видового складу дослідженої дендрофлори. Інші родини представлені одним або двома видами кожна. Встановлено, що кількісно переважають у досліджених насадженнях Platanus orientalis L., Acer platanoides L., A. pseudoplatanus L., Morus nigra L., Robinia pseudoacacia L., Populus alba L., Populus italica (Du Roi) Moench, Fraxinus excelsior L., Catalpa speciosa (Warder ex Barney) Warder ex Engelm. Аналіз загального стану деревних рослин вуличних насаджень показав, що більшість видів мають високий бал, що дає їм змогу ефективно виконувати фітомеліоративну та декоративну функції. Найбільшою життєздатністю у цих умовах відрізняється більшість досліджених екземплярів Platanus orientalis та Morus nigra. Кущі мало поширені в досліджених алейних насадженнях та характеризуються збідненим видовим складом. Збільшення частки чагарникових насаджень завдяки створенню бордюрів та живоплотів дасть змогу посилити санітарно-гігієнічну функцію досліджених насаджень, а також надасть насадженням ошатності та доглянутості.

Ключові слова: деревні рослини; життєздатність; благоустрій міста; зелені насадження.

Вступ. Невід'ємною частиною благоустрою сучасного міста $є$ його зелені насадження. Деревні та чагарникові насадження міської забудови складають парки, сквери, бульвари, алейні насадження вздовж автодоріг, внутрішньоквартальне озеленення. Деревні насадження $€$ одним із найважливіших довговічних елементів озеленення, які прикрашають населені пункти. Окрім декоративної функції, зелені насадження беруть участь у формуванні міського середовища, створюють особливі мікрокліматичні та санітарно-гігієнічні умови (Boiko et al., 2017, 2018; Kravchuk, Ryzhikov, 2011; Kokhno et al.,1983).

Під найбільший антропогенний прес потрапляють деревні насадження вздовж вулиць та автомагістралей (Melnik, 2015; Melnik, Melnik, 2013; Sklyarenko, Bessonova, 2019; Boiko et al., 2019). За матеріалами Регіональної доповіді про стан навколишнього природного середовища у Херсонській обл. за 2017 р., 84 \% викидів в атмосферне повітря міста надходить від пересувних джерел забруднення (Rehionaolna report..., 2018). Згідно зі статистичними даними, найбільшим забруднювачем міста $є$ автотранспорт, а також залізничний, авіаційний та водний транспорт. Загальний стан забруднення повітря оцінюють як високий, він зумовлений здебільшо- го підвищеним вмістом специфічних шкідливих речовин - фенолу, формальдегіду, оксиду азоту; з основних домішок - оксиду вуглецю і діоксиду азоту (Rehionaolna report..., 2018). Згубний вплив полютантів позначається як на асиміляційних органах рослин, так і на загальному стані рослин зокрема. Тому дослідження дендрофлори лінійних насаджень автодоріг з високим антропогенним навантаженням, аналіз видового складу насаджень та їх санітарного стану, критичний аналіз асортименту та його придатності у використанні об'єктів спеціального призначення належать до актуальних проблем сучасного міста.

Об'єктом дослідження є деревні рослини вуличних насаджень.

Предмет дослідження - таксономічна структура та загальний стан деревних рослин вуличних насаджень міста Херсон.

Метою нашого дослідження є встановлення таксономічної структури та загального стану деревних рослин вуличних насаджень міста Херсон.

Відповідно до мети, ми визначили завдання роботи:

1) встановлення видового складу та таксономічної структури деревних рослин вуличних насаджень території дослідження;

\section{Інформація про авторів:}

Бойко Тетяна Олексіївна, канд. біол. наук, доцент, кафедра лісового та садово-паркового господарства.

Email: t-boiko2015@ukr.net; https://orcid.org/0000-0003-3864-2036

Цитування за ДСту: Бойко Т. О. Таксономічна структура і стан вуличних насаджень міста Херсон. Науковий вісник НлтУ України. 2019, т. 29, № 8. С. 51-54.

Citation APA: Boiko, T. O. (2019). The taxonomic structure and condition of street plantings of the city of Kherson. Scientific Bulletin of UNFU, 29(8), 51-54. https://doi.org/10.36930/40290807 
2) дослідження загального стану рослин;

3) встановлення видів домінантів досліджених насаджень, їх відповідність умовам росту;

4) виявлення найбільш життєздатних порід для цих умов росту.

Знання сучасного стану та таксономічного складу міських зелених насаджень i, безумовно, пристосування рослин до умов місцезростання в урбанізованому середовищі є однією з важливих передумов успішного вирішення комплексу питань, пов'язаних із формуванням міського ландшафту, i поліпшення його еколого-естетичної цінності. Їх оновлення та реконструкція є одними зі шляхів до виконання рослинами екологічної, санітарно-гігієнічної та естетичної функцій, що загалом забезпечить сталий розвиток Херсону та поліпшить умови проживання населення.

Матеріали та методи дослідження. Матеріалами для написання роботи були власні спостереження, виголовних магістралях та вулицях Херсона. Загальна довжина обстежених вулиць становить близько 28,9 км, площа насаджень - 54,9 га. Ми докладно обстежили 8 автодоріг 3 найбільш напруженим автомобільним рухом (рис. 1).

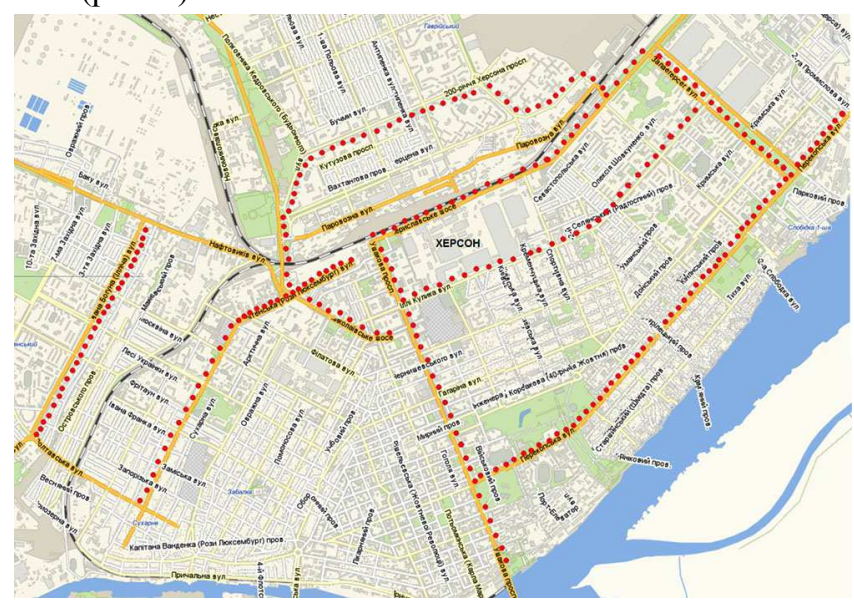

Рис. 1. Розміщення автодоріг, які підлягали обстеженню в межах Херсона

Камеральну обробку зразків деревних рослин виконували за загальноприйнятою методикою ботанічних досліджень. Латинські назви рослин навели за чеклістом (Mosyakin \& Fedoronchuk, 1999), українські назви за визначником (Determinant..., 1987) та М. А. Кохном (Kokhno, 2001, 2005).

Загальний стан рослин визначали за п'ятибальною шкалою С.I. Кузнєцова зі співавторами (Kuznetsov et al., 1998), де: в 5 балів оцінювали дерева без пригніченого росту з повноцінною листковою поверхнею; 4 бали надали деревам із ростом, що загалом відповідають нормі й мають близько 20-25\% недіючої поверхні; 3 бали деревам з ослабленим ростом, які мають близько $50 \%$ недіючої листкової поверхні; 2 бали - деревам із пригніченим ростом, приріст поточного року майже відсутній, мають $75-80 \%$ недіючої листкової поверхні; 1 бал - мертві та всихаючі, без поточного приросту дерева з $100 \%$ недіючою листковою поверхнею (Kuznetsov et al., 1998, Shepelyuk, 2017).

Результати дослідження. За результатами наших досліджень в одно- та дворядних насадженнях вздовж проїжджої частини вулиць Херсона було виявлено 59 видів деревних рослин, 3 культивари та 3 форми. У конані протягом 2018-2019 рр. маршрутним методом на

таксономічній структурі представленої дендрофлори за кількістю видів переважає відділ Magnoliophyta (55 види, 93,2 \%). Відділ Pinophyta представлений лише чотирма видами (6,8 \%). Провідними родинами дендрофлори проспектів є Rosaceae Juss. (7 видів), що становить 11,9 \% від загальної кількості видів та Salicaceae Lindl. (6 видів, 10,2 \%), Oleaceae Lindl. (5 видів, 8,5\%), Aceraceae Juss. (4 види, 6,8\%), Fabaceae Lindl. (4 види, 6,8\%) та Cupressaceae Bartl. (3 види, 5,1\%) (рис. 2). Зазначені родини охоплюють 49,3\% видового складу дослідженої дендрофлори. Інші родини представлені одним або двома видами кожна.

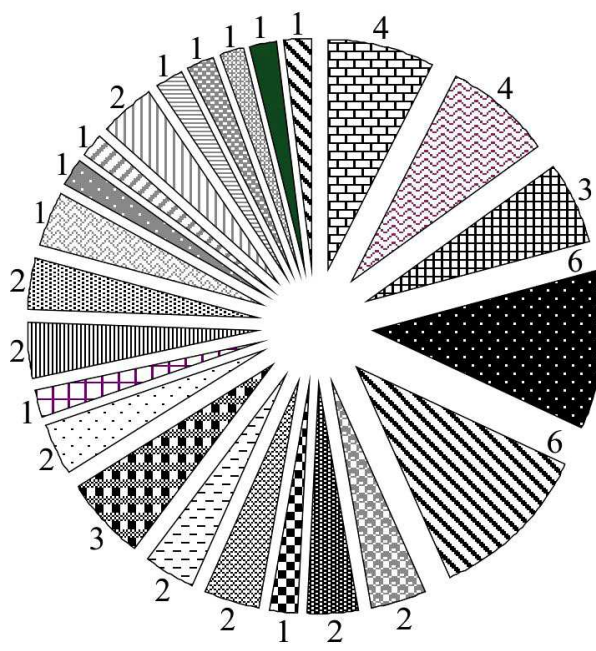

Aceraceae : Oleaceae $\boxplus$ Fabaceae Rosaceae Salicaceae Betulaceae 国Bignoniaceae Juglandaceae 응 Moraceae घCaesalpiniaceae 울 Cupressaceae $\square$ Pinaceae 曰Hippocastanaceae millatanaceae 멍 Vitaceae Tiliaceae $\square$ Simarubaceae oUlmaceae $\square$ Caprifoliaceae 目 Anacardiaceae 圆Elaeagnaceae 园 Tamaricaceae -Berberidaceae פMimosaceae

Рис. 2. Родинний спектр дендрофлори вуличних насаджень Херсона (числові значення вказують на кількість видів, якою представлена кожна родина)

За результатами проведених натурних обстежень встановлено, що кількісно переважають у досліджених насадженнях Platanus orientalis, Acer platanoides, A. pseudoplatanus, Morus nigra, Robinia pseudoacacia, Populus alba, Populus italica, Fraxinus excelsior, Catalpa speciosa (таблиця).

Таблиця. Видовий склад і загальний стан деревних рослин вуличних насаджень Херсона

\begin{tabular}{|c|l|c|c|}
\hline $\begin{array}{c}\text { № } \\
3 / \Pi\end{array}$ & \multicolumn{1}{|c|}{ Вид } & $\begin{array}{c}\text { Загальний } \\
\text { стан рос- } \\
\text { лин* }\end{array}$ & $\begin{array}{c}\text { Частка де- } \\
\text { ревних } \\
\text { рослин, \% }\end{array}$ \\
\hline 1 & Acer platanoides L. & 4 & 8,0 \\
\hline 2 & Acer saccharinum L. & 4 & 1,0 \\
\hline 3 & Acer pseudoplatanus L. & 4 & 7,0 \\
\hline 4 & Acer negundo L. & 3 & 2,0 \\
\hline 5 & Aesculus hippocastanum L. & 3 & 4,5 \\
\hline 6 & Ailanthus altissima (Mill.) Swingle & 5 & 1,0 \\
\hline 7 & Amorpha fruticosa L. & 5 & 0,1 \\
\hline 8 & Albizia julibrissin Durazz. & 4 & 0,1 \\
\hline 9 & Armeniaca vulgaris Lam. & 4 & 0,8 \\
\hline 10 & Biota orientalis (L.) Franco & 4 & 0,5 \\
\hline 11 & Berberis vulgaris L. & 5 & 0,1 \\
\hline 12 & Betula pubescens Ehrh. & 5 & 0,5 \\
\hline 13 & Betula pendula Roth & 5 & 0,1 \\
\hline 14 & Campsis radicans (L.) Seem. & 5 & 0,1 \\
\hline 15 & $\begin{array}{l}\text { Catalpa speciosa } \text { (Warder } \text { ex Bar- } \\
\text { ney) Warder ex Engelm. }\end{array}$ & 4 & 5,0 \\
\hline 16 & Cerasus avium (L.) Moench & 4 & 0,5 \\
\hline 17 & Cercis siliquastrum L. & 5 & 0,1 \\
\hline 18 & Corilus avelana L. & 4 & 0,1 \\
\hline 19 & Cotinus coggyria Scop. & 5 & 0,1 \\
\hline 20 & Cydonia oblonga Mill. & 4 & 0,2 \\
\hline 21 & Gleditsia triacanthos L. & 5 & 2,0 \\
\hline 22 & Gleditsia triacanthos f. inermis & 4 & 0,1 \\
\hline
\end{tabular}




\begin{tabular}{|c|c|c|c|}
\hline 23 & Eleagnus angustifolia $\mathrm{L}$. & 4 & 0,1 \\
\hline 24 & Fraxinus excelsior $\mathrm{L}$. & 5 & 6,0 \\
\hline 25 & Fraxinus excelsior 'Golden' & 5 & 0,9 \\
\hline 26 & Fraxinus lanceolata Borch. & 5 & 0,1 \\
\hline 27 & Forsythia viridissima Lindl. & 4 & 0,5 \\
\hline 28 & Juglans regia $\mathrm{L}$. & 3 & 2,0 \\
\hline 29 & Juniperus virginiana $\mathrm{L}$. & 4 & 0,1 \\
\hline 30 & Laburnum anagyroides Medik. & 5 & 0,1 \\
\hline 31 & Ligustrum vulgare L. & 4 & 0,5 \\
\hline 32 & Lonicera caprifolium L. & 5 & 0,1 \\
\hline 33 & Lonicera tatarica $\mathrm{L}$. & 5 & 0,1 \\
\hline 34 & Morus alba L. & 5 & 0,1 \\
\hline 35 & Morus nigra L. & 5 & 2,0 \\
\hline 36 & Morus nigra 'Pendula' & 5 & 3,0 \\
\hline 37 & $\begin{array}{l}\text { Parthenocissus tricuspidata (Si- } \\
\text { ebold \& Zucc.) Planch. }\end{array}$ & 5 & 0,6 \\
\hline 38 & Picea pungens Engelm. & 3 & 0,1 \\
\hline 39 & Picea pungens 'Glauca' & 4 & 0,5 \\
\hline 40 & Pinus pallasiana D. Don & 3 & 0,1 \\
\hline 41 & Populus italica (Du Roi) Moench & 2 & 11,5 \\
\hline 42 & Populus alba $\mathrm{L}$. & 4 & 4,5 \\
\hline 43 & Populus nigra $\mathrm{L}$. & 4 & 0,1 \\
\hline 44 & Platanus orientalis $\mathrm{L}$. & 4 & 10,5 \\
\hline 45 & Platanus occidentalis L. & 4 & 2,0 \\
\hline 46 & Prunus divaricata Ledeb. & 4 & 0,5 \\
\hline 47 & $\begin{array}{l}\text { Prunus cerasifera var. Pissardii } \\
\text { (Carriêre) Koehne }\end{array}$ & 4 & 0,1 \\
\hline 48 & Quercus robur $\mathrm{L}$. & 4 & 0,5 \\
\hline 49 & Robinia pseudoacacia L. & 4 & 7,5 \\
\hline 50 & Salix babilonica $\mathrm{L}$. & 4 & 0,1 \\
\hline 51 & Salix matsudana Koidz. & 4 & 0,1 \\
\hline 52 & Salix alba L. & 4 & 0,5 \\
\hline 53 & Sophora japonica $\mathrm{L}$. & 5 & 2,5 \\
\hline 54 & Sophora japonica 'Pendula' & 5 & 1,0 \\
\hline 55 & Sorbus aucuparia L. & 4 & 0,1 \\
\hline 56 & Spiraea x vanhouttei (Briot) Zabel. & 5 & 0,5 \\
\hline 57 & Spiraea media F. Schmidt & 5 & 0,5 \\
\hline 58 & $\begin{array}{l}\text { Symphoricarpos albus (L.) } \\
\text { S.F. Blake }\end{array}$ & 5 & 0,5 \\
\hline 59 & Syringa vulgaris L. & 4 & 2,5 \\
\hline 60 & Tamarix ramosissima Ledeb. & 4 & 0,1 \\
\hline 61 & Thuja occidentalis L. & 4 & 0,1 \\
\hline 62 & Tilia cordata Mill. & 4 & 1,5 \\
\hline 63 & Tilia platyphyllos Scop. & 4 & 0,3 \\
\hline 64 & Ulmus laevis Pall. & 4 & 0,6 \\
\hline 65 & Vitis vinifera $\mathrm{L}$. & 4 & 0,1 \\
\hline
\end{tabular}

65 Vitis vinifera $\mathrm{L}$.

Примітка: * - загальний стан рослин за шкалою ві-зуальної оцінки.

Встановлено, що більшість деревних рослин (платани, клен ясенелистий, катальпа, софора), які досягли пристигаючого віку, мають широкорозкидисті крони. Часто це заважає руху транспорту, що суперечить Державним будівельним нормам України (State building norms..., 2018). Отже, більшість 3 них потребують санітарної обрізки.

3 аналізу загального стану деревних рослин видно, що більшість видів рослин оцінили балом 4 та 5, що дає ім змогу ефективно виконувати фітомеліоративну та декоративну функції (Levon, 1999). Панівними породами вздовж автодоріг є Platanus orientalis, Populus italica, Acer platanoides, Populus alba, Robinia pseudoacacia, Acer negundo, Morus nigra, Fraxinus excelsior, Ulmus laevis (див. таблиця). Найвищою життєздатністю у цих умовах відрізняється більшість досліджених екземплярів Platanus orientalis та Morus nigra. Однак серед представників цих порід також трапляються екземпляри, які суховерхівкують, мають дупла, деякі повністю всохлі. Найбільша кількість фаутних екземплярів $\epsilon$ на Бериславському шосе, серед Populus italica, Populus alba та Acer negundo. Перші два види часто суховерхівкують, мають сухі гілки, кореневі відростки, тріщини та дупла. Також у Херсоні тополі часто підлягають кронуванню, що передбачає їх подальшу заміну новими екземплярами дерев. Однак рослини, кроновані 8-10 років тому, так і залишились рости. Функціональність та декоративність таких рослин і насаджень загалом, знижена. Acer negundo, який є досить стійким до полютантів у повітрі, останнім часом сильно ушкоджується Hyphantria cunea Drury, часто цілі гілки скелетуються та затягуються павутинням. Окремі екземпляри 2017 р. були пошкоджені цим шкідником на 60-100 \%.

Acer platanoides, A. saccharinum, A. pseudoplatanus, Tilia cordata, Catalpa speciosa на вулицях Олександрівській, Перекопській, Стрітенській часто мають некрозні плями та опіки листя, передчасне засихання та опадання листя. Листкові пластини Populus italica та $P$. alba кожного року уражаються іржею, гілки та стовбури - дереворуйнівними грибами (Boiko, 2016; Ogorodnikov, 1993).

Попри надзвичайно складні екологічні умови, догляд за деревними рослинами потрібно забезпечити регулярний та ретельний. Потрібно своєчасно видаляти сухостійні та фаутні дерева (Levon, 2004). Часто такі дерева або їх гілки падають на проїжджу частину, перешкоджаючи руху транспорту. Окрім того, вони є джерелом хвороб та шкідників. Видалення їх запобігає поширенню інфекції на сусідні здорові дерева.

Чагарники мало поширені в досліджених алейних насадженнях. Збіднений як їх видовий склад (див. таблиця), так і кількісне співвідношення з деревами. Часто ïx насадження мають хаотичний характер. Майже не виявлено бордюрів та зелених стін, які доречно використовувати в лінійних насадженнях вздовж автомагістралей. Збільшення частки чагарникових насаджень завдяки створенню бордюрів та живоплотів дасть змогу посилити санітарно-гігієнічну функцію досліджених насаджень, а також надасть насадженням ошатності та доглянутості.

Висновки. У результаті проведених досліджень встановлено, що у вуличних насадженнях вздовж основних автодоріг Херсона трапляється 59 видів деревних і чагарникових рослин, 3 культивари та 3 форми, які належать до 25 родин. Серед них найпоширеніші види родини Rosaceae Juss. (7 видів), що становить 11,9 \% від загальної кількості видів, та Salicaceae Lindl. (6 видів, 10,2 \%), Oleaceae Lindl. (5 видів, 8,5 \%), Aceraceae Juss. (4 види, 6,8\%), Fabaceae Lindl. (4 види, $6,8 \%$ ) та Cupressaceae Bartl. (3 види, 5,1\%). Вони охоплюють 49,3 \% видового складу дендрофлори вуличних насаджень. Переважають у вуличних насадженнях Platanus orientalis L., Acer platanoides L., A. pseudoplatanus L., Morus nigra L., Robinia pseudoacacia L., Populus alba L., Populus italica (Du Roi) Moench, Fraxinus excelsior L., Catalpa speciosa (Warder ex Barney) Warder ex Engelm. Високою життєздатністю та декоративністю характеризуються Platanus orientalis, Acer platanoides, A. saccharinum, A. pseudoplatanus, Populus alba, Morus nigra, Fraxinus excelsior, Ulmus laevis, Tilia platyphyllos, Sophora japonica, Sophora japonica 'Pendula', Fraxinus excelsior 'Golden' та є перспективними видами для озеленення і реконструкції зелених насаджень Херсона.

Scientific Bulletin of UNFU, 2019, vol. 29, no 8 


\section{Перелік використаних джерел}

Boiko, T. O., Dementieva, O. I., \& Kotovska, Yu. S. (2019). Assessment of biological and ecological properties of woody lianasin the conditions of the city of Kherson. Scientific Bulletin of UNFU, 29(5), 31-35. https://doi.org/10.15421/40290506

Boiko, T., \& Dementieva, O. (2018). The tree vegetation of the Kherson State Agrarian University Arboretum. Ukrainian journal of ecology, 8(2), 120-127. https://doi.org/10.15421/2018_318

Boiko, T. O. (2016). Non-communicable diseases and damages of tree plants of the Kherson. Scientific support for the rational use of the ecosystems in Southern Ukraine: Materials of the regional scientific-practical conference of teachers, young scientists, graduate students and students.

Boiko, T. O., Boiko, P. M., \& Sichna, Yu. M. (2017). Winter hardiness and frost resistance of Albizia julibrissin Durazz in conditions of Kherson. Plant introduction, 4(76), 63-68. [In Ukrainian].

DBN.V. 2.3-5: 2018. (2018). State building norms of Ukraine. Streets and roads of settlements. Kyiv: Minregion.

Higher plants. (1987). Determinant of higher plants of Ukraine. Kyiv: Scientific thought. [In Russian].

Kherson region. (2018). Rehionaolna report on the state of the environment in the Kherson region in 2017. Retrieved from: https://menr.gov.ua/files/docs/Reg.report/2017/Херсонська регіон альна_доповідь_2017.pdf

Kokhno, M. A. (2001). Catalog of dendroflora of Ukraine. Kyiv: Phitosotsiotsentr, $448 \mathrm{p}$.

Kokhno, M. A., et al. (1983). Dendroflora of cities of southern Ukraine. Ukrainian Botanical Journal, 40(5), 12-14.

Koxno, M. A., Trofymenko, N. M., \& Parxomenko, L. (2005). Dendroflora of Ukraine. Wild and cultivated trees and bushes. (Part 2). Kyiv: Fitosociocentr, 716 p. [In Ukrainian].

Kravchuk, L. A., \& Ryzhikov, V. A. (2011). Structure, condition and stability of tree stands in planting along streets and roads in cities of Belarus. Nature use, 20, 81-89.
Kuznetsov, S. I., Levon, F. M, Pilipchuk, V. F., \& Shumik, M. I. (1998). Ecological prerequisites for optimization of street plantations in Kiev. Questions of bioindication and ecology, 3, 57-64. Zaporozhye. [In Ukrainian].

Levon, F. M. (1999). Plants of cultural dendroflora in the anthropogenically transformant-walled environment. Bulletin of the State Nikita Botanical Garden, 79, 120-127. Yalta.

Levon, F. M. (2004). Biologic-ecological of a basis of creation of green plantings in conditions urbagenic and technogenic environments. Doctoral dissertation for agricultural sciences (06.03.01 - Forest Plantation and Phytomelioration). Lviv, $42 \mathrm{p}$.

Melnik, T. I. (2015). State street planting of central part of the city of Sumy. (Ser. Agronomy and Biology). Bulletin of Sumy NAU, 9(30), 221-226.

Melnik, T. I., \& Melnik A. V. (2013). Species composition and quantitative participation of tree species in street plantations of Sumy city. (Ser. Forestry and ornamental horticulture). Scientific Bulletin of the National University of Life and Environmental Sciences of Ukraine, 187(3), 49-55.

Mosyakin, S. L., \& Fedoronchuk, M. N. (1999). Vascular plants of Ukraine. A nomenclatural checklist. Kyiv, $346 \mathrm{p}$.

Ogorodnikov, A. Ya. (1993). Methods of visual assessment of bioecological properties of woody plants in the settlements of the steppe zone. Itogi introduktsii rasteniy. Rostov-on-Don: RGU, pp. 50-58. [In Russian].

Shepelyuk, M. O. (2017). The dendroflora of Lutsk: formation, species composition, biological and ecological peculiarities. Candidate dissertation for agricultural sciences (06.03.01 - Forest Plantation and Phytomelioration). Kyiv, 24 p. [In Ukrainian].

Sklyarenko, A. V., \& Bessonova, V. P. (2019). Species diversity of tree plantations in industrial enterprise protective zones (Zaporizhzhya, Ukraine). Acta Biologica Sibirica, 5(1), 167-174.

\section{THE TAXONOMIC STRUCTURE AND CONDITION OF STREET PLANTINGS OF THE CITY OF KHERSON}

Tree plantations are one of the most important durable elements of landscaping that decorate settlements. Green spaces are involved in shaping the urban environment, creating special microclimatic and sanitary conditions. Tree plantations along the streets and highways are experiencing the largest anthropogenic press. Transport is the city's largest polluter according to statistics. The overall air pollution in the City of Kherson is rated as high. Therefore, studies of the dendroflora of linear plantings of highways with high anthropogenic load, analysis of the species composition of the plantations and their sanitary status, critical analysis of the assortment and its suitability for the use of special purpose objects are relevant to the current problems of the modern city. As a result of our research, 59 species of woody plants, 3 cultivars and 3 forms were found in plantations along the Kherson roadways. In taxonomic structure, the number of species is dominated by the Magnoliophyta (55 species, 93.2\%). Pinophyta is represented by only 4 species (6.8 \%). The leading families of the dendroflora of the roadways are Rosaceae Juss. ( 7 species, which are $11.9 \%$ of the total species number), Salicaceae Lindl. (6 species, 10.2\%), Oleaceae Lindl. (5 species, $8.5 \%$ ), Aceraceae Juss. (4 species, $6.8 \%$ ), Fabaceae Lindl. (4 species, $6.8 \%$ ), Cupressaceae Bartl. (3 species, $5.1 \%$ ). These families account for $49.3 \%$ of the species composition of the studied dendroflora. The results of the field survey show that quantitatively studied in plantations Platanus orientalis L., Acer platanoides L., A. pseudoplatanus L., Morus nigra L., Robinia pseudoacacia L., Populus alba L., Populus italica (Du Roi) Moench, Fraxinus excelsior L., Catalpa speciosa (Warder ex Barney) Warder ex Engelm dominate. The analysis of the general state of woody plants has revealed that most species assessed high score. This allows them to effectively perform phytomeliorative and decorative functions. The dominant species on most motorways are Platanus orientalis, Populus italica, Acer platanoides, Populus alba, Robinia pseudoacacia, Acer negundo L., Morus nigra, Fraxinus excelsior, Ulmus laevis Pall. The most viable under these conditions, most studied specimens Platanus orientalis and Morus nigra differ. Shrubs are not widespread in the studied plantations. Their species composition is depleted compared to trees. They are often planting chaotic. Almost no borders and green walls have been found that are appropriate to use in linear plantations along roadways. Increasing the share of shrubs through the creation of borders and hedges will enhance the sanitary and hygienic function of the investigated plantations, as well as give the plant neat and tidy appearance.

Keywords: woody plants; viability; city improvement; green space. 